\title{
Perancangan Kampanye Kesadaran Pola Makan Sehat Bagi Masyarakat Kota Palembang
}

\author{
Yuarisya Nurauliani ${ }^{1)}$, Heri Iswandi ${ }^{2)}$, Mukhsin Patriansyah ${ }^{3)}$ \\ ${ }^{1223)}$ Program Studi Desain Komunikasi Visual Fakultas Ilmu Pemerintahan dan Budaya \\ Universitas Indo Global Mandiri \\ Jl. Jend. Sudirman No. 629 KM.4 Palembang. Kode Pos 30129

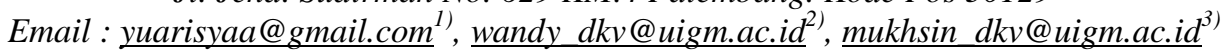

\begin{abstract}
Having a body that is always healthy is everyone's dream. Food that we think is healthy is not necessarily 'healthy' for the body. Especially with the mushrooming of food and process drinks or packaging, fast food, as well as young fried foods found everywhere. The delicious and savory taste on the tongue makes anyone like it. However, do you know if it contains a lot of high calories and bad substances for the body. Starting from MSG, preservatives, bad fats, sugar and much more. All that will be buried in the body for a long time will cause various diseases such as hypertension, heart disease, diabetes, obesity, to cancer. One way to control is by calculating the daily calories that enter the body. Calories are the amount of energy in food. The key to healthy weight is knowing how many calories in food you consume so that it can be adjusted to the amount of energy burned by the body.
\end{abstract}

Keywords : Eat Healthy, Calories, Processing Food

\begin{abstract}
Abstrak
Memiliki tubuh yang selalu sehat adalah impian semua orang. Makanan yang selama ini kita pikir sehat belum tentu 'sehat' bagi tubuh. Apalagi dengan menjamurnya makanan dan minuman proses atau kemasan, fast food, serta makanan serba goreng yang muda didapatkan di mana-mana. Rasanya yang enak dan gurih di lidah membuat siapapun menyukainya. Namun, tahukah jika di dalamnya banyak mengandung kalori yang tinggi dan zat jahat bagi tubuh. Mulai dari MSG, pengawet, lemak jahat, gula dan masih banyak lagi. Semua itu akan tertimbun dalam tubuh dalam kurun waktu yang lama akan menimbulkan berbagai macam penyakit seperti hipertensi, jantung, diabetes, obesitas, hingga kanker.Salah satu cara untuk mengontrol adalah dengan metode menghitung kalori harian yang masuk ke dalam tubuh. Kaloriadalah takaran energi dalam makanan. Kunci berat badan sehat adalah mengetahui berapa kandungan kalori dalam makanan yang dikonsumsi sehingga dapat disesuaikan dengan jumlah energi yang dibakar oleh tubuh.
\end{abstract}

Kata kunci : Makan Sehat, Kalori, Makanan Proses 


\section{Pendahuluan}

Kesehatan yang baik didukung oleh beberapa faktor pendukung, seperti faktor makanan. Makanan adalah bahan utama yang diperlukan oleh tubuh untuk dikonsumsi agar memiliki tenaga atau energi untuk melakukan aktifitas kehidupan sehari-hari. Selain itu makanan juga membantu memberikan ketahanan tubuh serta sebagai penentu kualitas pertumbuhan. Namun dalam hal memilih makanan, ada hal-hal tertentu yang harus diperhatikan agar kegiatan makan dapat menjadi sesuatu yang baik bagi kesehatan tubuh. Pola makan sehat yang baik adalah pola makan yang mengonsumsi makanan dari rantai makanan paling bawah. Dengan memakan makanan dalam bentuk yang paling alami, otomatis asupan vitamin, mineral, dan zat-zat penting lainnya menjadi lebih tinggi dan lebih baik. (Jonathan V. Wright dan Linda Johnson Larsen, 2011: 24)

Permasalahan mendasar yang mempunyai peranan sangat penting dalam menurunnya kualitas kesehatan adalah pola makan yang tidak sehat. Kebanyakan dari masyarakat memang cukup makan, tetapi tidak cukup mendapatkan nutrisi dari makanan tersebut karena memakan makanan yang salah, artinya bahan dan cara mengolahnya membuat makanan tersebut menjadi tidak sehat. (Renza Fran, Wawacara, 2018.) ungsi makanan kini bukan lagi sekadar untuk kesehatan dan kehidupan. Makanan sudah bergeser kepada kenikmatan serta kepuasan lidah semata. Sering kali masyarakat lupa memperhatikan kandungan gizi dan cara pengolahan makanan yang di makan. Sering kali masyarakat makan karena selera, bukan karena lapar dan kebutuhan. Sering kali masyarakat lupa memperhatikan jadwal makan dan porsi makan. Masyarakat banyak makan karbohidrat kosong, banyak makan gula, banyak makan makanan proses dan makanan cepat saji, kurang makan serat, dan kurang minum. Inilah yang disebut sebagai pola makan modern (modern diet) atau disebut juga "Industrialized diet", yaitu pola makan modern yang banyak dilakoni orang di mana-mana di zaman modern saat ini. (Irnawati Naingolan, Wawancara, 2018.)

Tujuan Perancangan ini dibuat agar masyarakat dapat lebih memahami tentang pola makan sehat dengan menggunakan metode kalori harian yang tentunya berbeda pada tiap individu keperluan kalori harian yang dibutuhkan. Sehingga masyarakat bisa mendapatkan kesehatan untuk beraktifitas sehari-hari serta jauh dari berbagai macam penyakit kronis yang sering melanda karena makanan yang dikonsumsi tidak sesuai dengan apa yang tubuh perlukan.

Komunikasi visual tidak serta merta hanya mampu memberikan pemecahan terhadap permasalahan yang ada dan hanya berkaitan dengan eksekusi visual, namun juga mampu memilih media yang tepat dan relevan untuk membangun komunikasi dengan masyarakat ataupun pemerintah. Mural adalah salah satu media yang efektif dan akhir-akhir ini dijadikan media penyampai pesan secara visual.Dalam kenyataan empirik, seni dapat dilihat sebagai cara hidup yang bertalian dengan keindahan. Adapun politik berkaitan dengan persaingan kekuasaan dan caracara menggunakan kekuasaan. Seni dan politik yang dimiliki individu dapat disebut pengetahuan seni dan politik. Karena kebutuhan yang dihadapi berbeda-beda, terdapat kemungkinan prilaku yang berbeda antara satu individu dan individu lain. Tantangan yang dihadapi ini mendorong manusia melakukan antisipasi. Yaitu suatu proses dalam kondisi seseorang untuk mempersepsikan, merumuskan, atau mencari alternatif dalam memecahkan masalah yang dihadapi. Dalam konteks seni, reaksireaksi yang muncul melahirkan aneka ragam kreasi seni. Dalam konteks politik, tanggapan-tanggapan itu bisa muncul sebagai strategi manipulatif untuk tujuan politik. Dalam konteks seni, tanggapan-tanggapan itu bisa muncul sebagai penghalusan yang bersifat integratif atau transformasi bentuk dari dorongan yang dasariah menjadi bentuk yang bermartabat. (Iswandi, 2018).

\section{A. Landasan Teori}

\section{Promosi Kesehatan}

Promosi kesehatan tidak terlepas dari kegiatan atau usaha menyampaikan pesan kesehatan kepada masyarakat, kelompok, atau individu. Dengan adanya pesan tersebut makan diharapkan masyarakat, kelompok, atau individu dapat memperoleh pengetahuan tentang kesehatan yang lebih baik. Pengetahuan tersebut akhirnya diharapkan dapat berpengaruh terhadap prilaku. Dengan kata lain, adanya promosi tersebut diharapkan dapat membawa akibat terhadap perubahan prilaku sasaran.

Promosi kesehatan juga merupakan suatu kegiatan yang mempunyai masukkan (input), proses dan keluaran (output). Kegiatan promosi kesehatan guna mencapai tujuan yakni perubahan perilaku, dipengaruhi oleh banyak faktor. Di samping faktor metode, faktor materi dan pesannya, petugas yang melakukannya, juga alat-alat bantu/alat peraga atau media yang dipakai. Agar mencapai suatu hasil yang optimal, maka faktor-faktor tersebut harus bekerja sama secara harmonis. Hal ini berarti bahwa untuk masukkan (sasaran) tertentu harus menggunakan cara tertentu pula. Materi juga harus disesuaikan dengan sasaran atau media. Untuk sasaran kelompok maka metodenya harus berbeda dengan sasaran massa dan sasaran individual. Untuk sasaran massa pun harus berbeda dengan sasaran individual dan kelompok.

\section{Desain Komunikasi Visual}

Menurut Supriyono dalam buku Desain Komunikasi Visual Teori dan Aplikasi mengungkapkan bahwa ilmu Desain Komunikasi Visual muncul untuk menyampaikan informasi menggunakan bahasa visual atau gambar. Selain itu bahasa visual digunakan sebagai sarana komunikasi yang sama pentingnya dengan bahasa verbal atau tulisan. Oleh karena itu pesan selalu menggunakan unsur-unsur visual atau ilustrasi di samping teks. (Supriyono, $2010: 2$ ).

Komunikasi visual yang merupakan sebuah rangkaian proses penyampaian kehendak atau maksud tertentu kepada pihak lain dengan penggunaan media penggambaran yang hanya terbaca oleh indera 
penglihatan. Komunikasi visual mengkombinasikan seni, lambang, tipografi, gambar, desain grafis, fotografi, ilustrasi, dan warna dalam penyampaiannya.

Dalam perancangan kampanye kesadaran masyarakat ini tidak lepas dari teori desain komunikasi visual dimana nantinya setiap pesan akan di sampaikan melalui bentuk visual, yaitu melalui ilustrasi dan juga bahasa verbal. Sehingga tujuan dari pesan yang akan dibuat dapat tersampaikan kepada masyarakat.

3. Semiotika

Dalam konsep ini teori semiotika Charles Sanders Pierce dengan system kategorinya sangat tepat digunakan dalam penelitian yang melibatkan artefak visual. Peirce mengemukakan teori segitiga makna atau triangle meaning yang terdiri dari tiga elemen utama, yaitu tanda (representamen) ialah sesuatu yang dapat mewakili sesuatu yang lain dalam batas-batas tertentu (Eco, 1979: 15). Tanda akan selalu mengacu ke sesuatu yang lain, oleh Pierce disebut objek (denotatum). Mengacu berarti mewakili atau menggantikan, tanda baru dapat berfungsi bila diinterpretasikan dalam benak penerima tanda melalui interpretant. Jadi interpretant ialah pemahaman makna yang muncul dalam diri penerima tanda. Artinya, tanda baru dapat ditangkap dan pemahaman terjadi berkat ground, yaitu pengetahuan tentang sistem tanda dalam suatu masyarakat. (Sumbo, 2009: 12). Dalam perancangan kampanye kesadaran pola makan sehat bagi masyarakat Kota Palembang ini menggunakan objek-objek visual berupa karakter dan juga tanda-tanda.

4. Ilustrasi

Menurut Adi Kusrianto dalam buku Pengantar Desain Komunikasi Visual menjelaskan bahwa sebuah ilustrasi mampu membantu pembaca untuk menggambarkan apa yang tertulis dalam suatu artikel maupun cerita. Sedangkan ilustrasi menurut definisi adalah seni gambar yang dimanfaatkan untuk memberi penjelasan atas suatu maksud atau tujuan secara visual. Dalam perkembangannya, ilustrasi secara lebih lanjut ternyata tidak hanya berguna sebagai sarana pendukung cerita, tetap dapat juga menghiasi ruang kosong (Kusrianto, 2009: 140).

\section{Tipografi}

Tipografi dalam hal ini huruf yang tersusun dalam sebuah alfabet merupakan media penting komunikasi visual. Media yang membawa manusia mengalami perkembangan dalam cara berkomunikasi. Komunikasi yang berakar dari simbol-simbol yang menggambarkan sebuah objek (pictograph), berkembang menjadi simbol-simbol yang merepresentasikan gagasan yang lebih kompleks serta konsep abstrak yang lain (ideograph). Kemudian berkembang menjadi bahasa tulis yang dapat dibunyikan dan memiliki arti (phonograph-setiap tanda atau huruf menandakan bunyi). Bentuk/rupa huruf tidak hanya mengidentifikasi sebuah bunyi dari suatu objek. Bentuk/rupa huruf tanpa disadari menangkap realitas dalam bunyi. Lebih dari sekedar lambang bunyi, bentuk/rupa huruf dalam suatu kumpulan huruf (font) dapat memberi kesan tersendiri yang dapat mempermudah khalayak menerima pesan atau gagasan yang terdapat pada sebuah kata atau kalimat. Bisa dibayangkan bila huruf tidak pernah ada, dalam penyampaian sebuah pesan atau gagasan pasti akan membutuhkan waktu yang lama, dan bisa dibayangkan bila bentuk/rupa huruf seragam/sama. Huruf menjadi sesuatu yang memiliki makna ganda, huruf dapat menjadi sesuatu yang dapat dilihat (bentuk/rupa huruf) dan dapat menjadi sesuatu yang dapat dibaca (kata/kalimat). Selain itu huruf memiliki makna yang tersurat (pesan/gagasan) dan makna yang tersirat (kesan). Selain itu pengaruh perkembangan teknologi digital yang sangat pesat pada masa kini membuat makna tipografi semakin meluas. Menurut Rustan (2001:16) tipografi dimaknai sebagai "segala disiplin yang berkenaan dengan huruf".

6. Prinsip Seni Rupa

a. Ruang

Ruang adalah suatu bentuk yang didapat dari himpunan bidang-bidang yang berdimensi panjang, lebar dan tinggi. Ruang juga terbagi dua macam yaitu ruang nyata dan ruang semu. Keberadaan ruang sebagai salah satu unsur visual sebenarnya tidak dapat diraba namun bisa dirasakan.

b. Warna

Warna merupakan salah satu unsur visual yang berkaitan dengan bahan yang mendukung keberadaanya yaitu ditentukan oleh jenis pigmennya. Kesan warna yang diterima oleh mata lebih ditentukan oleh cahaya.

c. Keseimbangan

Keseimbangan adalah konvergensi elemen-elemen atau bagian-bagian untuk menciptakan suatu desain yang membuat penampilan keseluruhan. Keseimbangan visual bisa diciptakan secara simetris maupun asimetris.

d. Posisi

Posisi adalah penempatan elemen-elemen dalam kaitannya antara satu dengan satu elemen lainnya dalam format visual. Posisi menciptakan poin fokus yang selanjutnya mengarahkan mata audiens.

7. Teori Kampanye

Menurut Kotler \& Roberto (Philip Kotler, Eduardo L. Roberto, 1989) kampanye sosial dibuat untuk merubah sikap dan perilaku masyarakat umum maupun tertentu. Sedangkan menurut Leslie B. Snyder, Kampanye komunikasi adalah sebuah asktifitas terorganisir yang ditujukan untuk khalayak tertentu, dikerjakan dalam jangka waktu yang ditentukan dan untuk mencapai tujuan tertentu.Beberapa ahli komunikasi mengakui bahwa definisi yang diberikan Rogers dan Storey adalah yang paling popular dan dapat diterima dikalangan ilmuwan komunikasi. Hal ini didasarkan kepada dua alasan. Pertama, definisi tersebut secara tegas menyatakan bahwa kampanye merupakan wujud tindakan komunikasi, dan alasan kedua adalah bahwa definisi tersebut dapat mencakup keseluruhan proses dan fenomena praktik kampanye yang terjadi dilapangan.

Setiap aktivitas kampanye komunikasi setidaknya mengandung empat hal, yaitu tindakan kampanye yang ditujukan untuk menciptakan efek atau dampak tertentu, 
jumlah khalayak sasaran yang besar, dipusatkan dalam kurun waktu tertentu, dan melalui serangkaian tindakan komunikasi yang terorganisir. Kampanye juga memiliki ciri atau karakteristik yang lainnya, yaitu sumber yang jelas, yang menjadi penggagas, perancang, penyampai sekaligus penanggung jawab suatu produk kampanye (campaign makers), sehingga setiap individu yang menerima pesan kampanye dapat mengidentifikasi bahkan mengevaluasi kredibilitas sumber pesan tersebut setiap saat. Segala tindakan dalam kegiatan kampanye dilandasi oleh prinsip persuasi, yaitu mengajak dan mendorong public untuk menerima atau melakukan sesuatu yang dianjurkan atas dasar kesukarelaan. Dengan demikian kampanye pada prinsipnya adalah contoh tindakan persuasi secara nyata. Dalam ungkapan Perloff (1993) dikatakan "Campaigns generally exemplify persuasion in action". (Venus, 2004:7)

\section{Pembahasan}

Dalam kehidupan sehari-hari, masyarakat membutuhkan makanan untuk dapat bertahan hidup. Akan tetapi, tidak sembarang makanan yang dapat dikonsumsi oleh masyarakat. Makanan sehat dengan kandungan gizi yang cukup. Makanan sehat adalah dengan meramu berbagai jenis makanan yang seimbang, sehingga terpenuhi seluruh kebutuhan gizi bagi tubuh dan mampu dirasakan secara fisik dan mental (Prasetyono, 2009). Makanan sehat adalah makanan dalam arti yang sesungguhnya dan mampu menikmati makanan tersebut. Makanan sehat harus terdiri dari makanan utama dan makanan penunjang. Makanan sehat tersebut juga dikenal dengan istilah 4 sehat dan 5 sempurna, tetapi kepopulerannya sudah mulai memudar karena berbagai alasan.

Kesehatan manusia terletak pada perut. Bila perut dijejali dengan makanan yang baik dan sehat, tentu akan sehat pula seluruh tubuh manusia. Namun, bila tubuh manusia itu selalu dijejali racun, ataupun zat-zat yang membahayakan tubuh, maka perut akan menjadi bom waktu bagi kesehatan tubuh. Bom waktu itu pun sewaktu-waktu bisa meledak dengan munculnya berbagai penyakit.

Kelebihan kolestrol dan lemak jahat akan menghambat peredaran darah dari dan menuju jantung, dan juga ke seluruh tubuh. Bila aliran darah menuju jantung itu tersumbat, maka dapat dipastikan bahwa penyakit jantung akan mengintai. Bahkan, seseorang bisa mati mendadak apabila terkena serangan jantung koroner yang orang awam biasa menyebutnya dengan penyakit angin duduk.

Bila aliran darah dari dan menuju jantung mengalami hambatan, tentu kinerja jantung akan semakin cepat dan tidak teratur. Karena begitu cepatnya jantung memompa darah, maka muncullah tekanan darah tinggi yang dapat menyebabkan pecahnya pembuluh darah otak. Akhirnya, pecahnya pembuluh darah tersebut dapat menimbulkan penyakit mematikan yang bernama stroke.

Makanan juga bisa menyebabkan kanker pada manusia, terutama kanker saluran pencernaan. Misalnya, terlalu sering mengonsumsi makanan yang diasap atau diasamkan dapat meningkatkan risiko terjadinya kanker lambung. Kemudian, pola makan tinggi lemak dapat meningkatkan risiko terjadinya kanker usus besar, rahim, dan payudara.

Peminum alkohol memiliki risiko yang lebih tinggi terhadap kanker. Konsumsi alkohol sebanyak dua gelas atau lebih per hari dapat meningkatkan risiko terjadinya kanker mulut, kerongkongan, hati, dan payudara. Risiko kanker tersebut akan meningkat lagi bila disertai merokok atau menggunakan produk tembakau.

Segala penyakit yang datang bermula dari asupan makanan, minuman, rokok dan berbagai zat luar ke dalam tubuh. Terutama beberapa makanan yang menjadi racun jika sering dikonsumsi oleh tubuh, salah satunya pola konsumsi junk food. Makanan sampah atau junk food adalah salah satu penyebab mengapa racun mengendap dalam tubuh. Namun ironisnya, pola konsumsi junk food menjadi tren dikalangan masyarakat. Entah itu sebagai gaya hidup, prestise, demi alasan kepraktisan, efesiensi hidup, ataupun alasan-alasan lain yang menjadi pembenar untuk mengonsumsi makanan sampah tersebut.

Pada saat ini, hantu kesehatan bagi tubuh manusia modern adalah junk food. Semua sudut kota telah menyajikan berbagai gerai makanan yang mempertontonkan makanan sampah tersebut. Dengan berbagai kemasan yang menarik dan menggoda selera, mereka berusaha menarik konsumen yang rata-rata membeli lantaran dorongan prestise semata. Selain hanya mengutamakan rasa dan penampilan, kandungan nutrisi makanan ini sangat rendah. Semantara itu kandungan kalorinya terlalu tinggi. Secara umum, yang termasuk dalam golongan junk food adalah makanan berkadar garam tinggi, bergula tinggi, berlemak tinggi, namun kandungan gizi lain nya seperti protein, vitamin, dan mineral tipis.

Dengan kadar lemak yang terlalu tinggi, mengakibatkan menumpuknya kadar lemak dalam darah sehingga kolestrol pun menjadi tinggi. Akibatnya, pembuluh darah menjadi tidak lancar, sehingga penyakit jantung dan stroke pasti akan menyerang. Tingginya kadar gula dalam jenis makanan sampah ini juga dapat menyebabkan penyakit diabetes, salah satu penyakit yang berbahaya bagi kehidupan manusia.

Namun ironisnya, junk food malah menjadi makanan favorit bagi kalangan masyarakat saat ini. Anehnya lagi, meski harganya diatas rata-rata, makanan sampah ini digemari oleh hampir semua kalangan. Terutama kaum muda, bahkan mengonsumsinya seakan-akan hal tersebut telah menjadi bagian gaya hidup sehari-hari. Hal ini memang tidak bisa dihindari, karena makanan jenis ini biasanya menawarkan sebuah prestise bagi para konsumennya.

Ada beberapa sebab yang membuat junk food sangat berbahaya bagi kesehatan tubuh, dan penyebabnya tiada lain adalah kandungan berbagai unsur yang apabila dikonsumsi berlebihan dan dalam intensitas yang sering, maka dapat membahayakan tubuh. Kandungan yang terdapat pada makanan sampah tersebut adalah: 


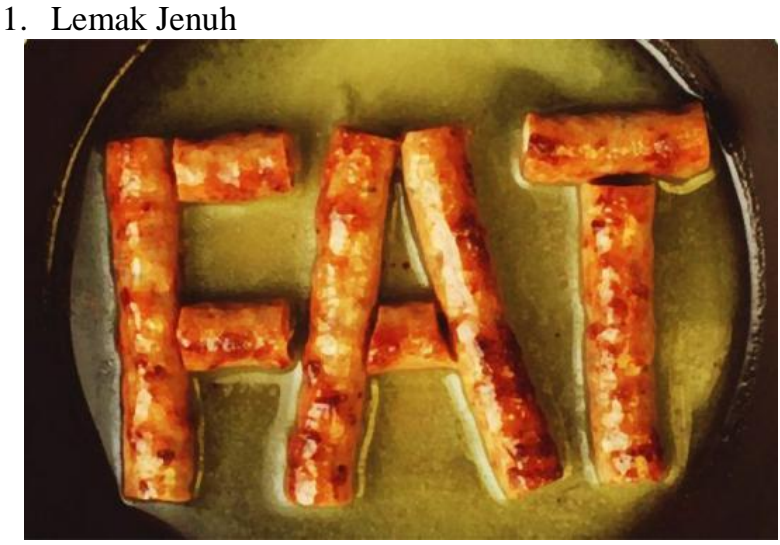

Gambar 1. Lemak Jenuh

Sumber: pinkkorset.com

Diakses: 30/072018

Sebagai hasil olahan industri makanan, junk food biasanya banyak mengandung lemak jenuh. Oleh karena itu harganya sangat murah dan ketika dipanaskan dapat bertahan pada temperatur tinggi. Bahayanya, lemak jenuh bisa menjadi biang kegemukkan dan meningkatnya kadar kolestrol dalam darah. Apabila kondisi tersebut terjadi pada seseorang, maka masalah kesehatan serius lainnya pun akan terpicu. Kanker penyakit jantung dan stroke adalah contoh penyakit yang diakibatkan oleh kandungan lemak jenuh tinggi.

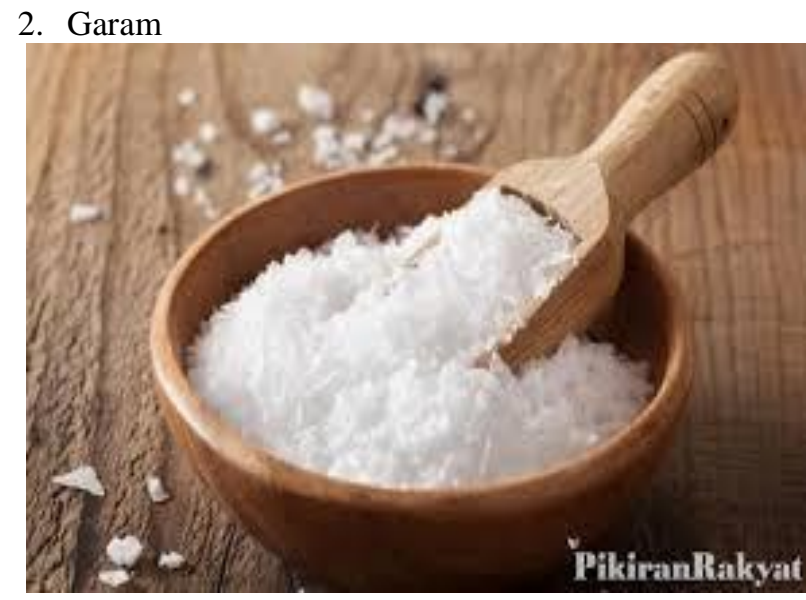

Gambar 2. Garam

Sumber: pikiran rakyat.com

Diakses: 30/072018

Garam atau monosodium klorida atau natrium klorida merupakan kandungan junk food yang juga perlu disikapi dengan hati-hati. Kadar garam yang baik untuk dikonsumsi adalah tidak lebih dari 5 gram per hari, dan sangat dianjurkan bagi orang dewasa yang memiliki tekanan darah normal. Sementara itu, kandungan garam pada junk food biasanya relatif tinggi. Manusia memang membutuhkan zat perasa ini untuk membantu fungsi metabolisme tubuh. Namun, bila berlebihan mengonsumsi penghilang rasa hambar ini, maka risiko tekanan darah tinggi akan meningkat.
3. Gula

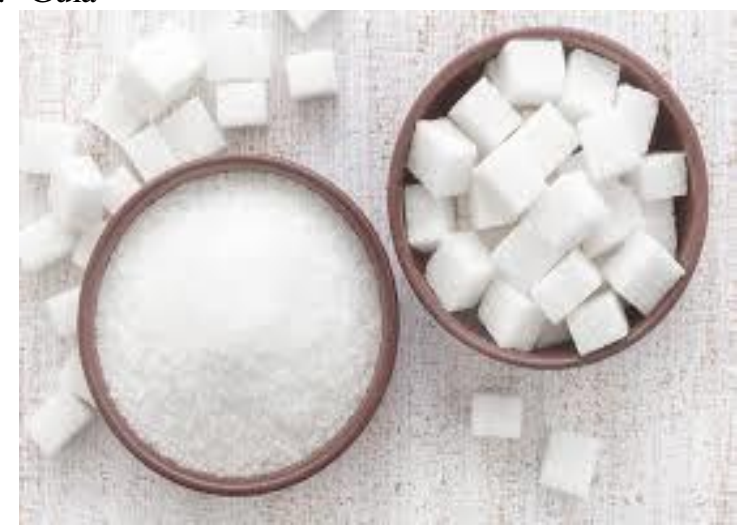

Gambar 3. Gula

Sumber: hellosehat.com

Diakses: 30/072018

Kandungan junk food lainnya yang tak kalah tinggi adalah gula. Minuman ringan, biskuit, kue, dan permen mengandung gula yang tidak sedikit. Kendati secara tidak langsung berhubungan dengan penyakit jantung dan diabetes, kelebihan gula bisa mengakibatkan kegemukan atau obesitas pada usia muda. Masalah kesehatan lainnya yang bisa disebabkan oleh kadar gula berlebihan adalah tooth decay atau kerusakkan gigi, mengurangi level kolestrol berguna, meningkatkan kadar lemak dalam darah yang berhubungan dengan diabetes, dan penyakit jantung.

\section{Penambah Cita Rasa atau Zat Aditif Sintesis}

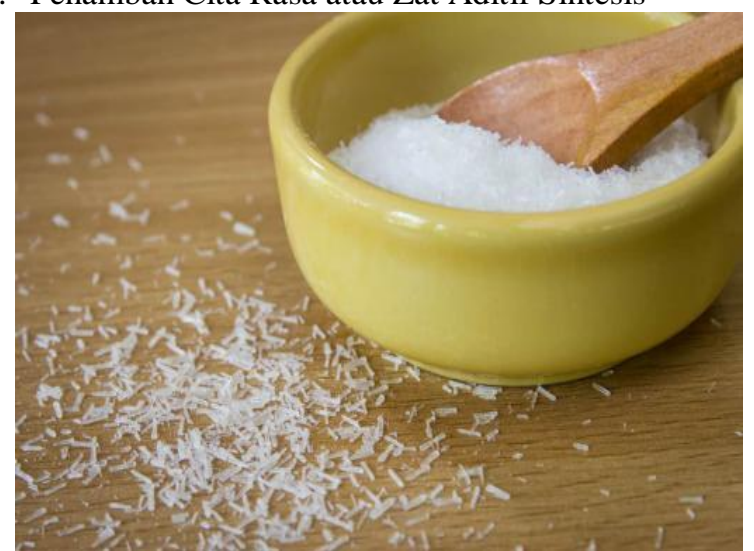

Gambar 4. Monosodium Glutamat

Sumber: hellosehat.com

Diakses: 30/072018

Zat lain yang terkandung dalam junk food secara berlebih adalah bahan tambahan atau zat aditif. Umumnya, zat aditif ini digunakan untuk mengawetkan dan mempertahankan warna, rasa, dan bentuk. Zat aditif adalah sejenis natrium atau sodium yang menjadi sumber utama garam dapur dan vetsin atau MSG (Monosodium Glutamat). Unsur inilah yang menjadi penggugah selera makanan cepat saji atau junk food. Kadar natrium atau sodium dalam 1 gram garam dapur setara dengan kadar natrium atau sodium yang terkandung dalam 3 gram (1 
sendok teh) MSG atau vetsin. 1 gram garam dapur membuat semangkuk makanan menjadi asin.

Selain makanan yang tidak seimbang dan tidak sehat, ada faktor lain yang juga memengaruhi kesehatan tubuh. Faktor tersebut lebih cendrung pada sisi psikologis dalam memandang suatu pola makan. Jika tidak diperhatikan dengan baik, disadari atau tidak, manusia tengah menciptakan sebuah pola makan yang tidak sehat. Menurut ahli gizi RS. RK. Charitas Palembang, Renza Fran, pola makan sebagian masyarakat di kota Palembang hampir tidak sehat. Porsi makan besar terlalu banyak, kemudian diselingi makanan kecil yang terlalu sering. Obesitas, penyakit jantung, dan stroke menjadi fenomena yang sangat ditakuti. Oleh sebab itu, ungkapan "makanlah di saat lapar dan berhentilah sebelum kenyang" patut untuk diperhatikan. Bagaimanapun, dari sanalah keseimbangan pola makan akan tercipta.

Dari berbagai data yang telah didapat, segala sesuatu yang ada disekitar manusia sebenarnya sudah memberikan yang terbaik bagi kehidupannya. Hanya saja manusialah yang harus bisa memanfaatkan secara maksimal dan seimbang demi menjaga kelangsungan hidup. Oleh karena itu, penulis akan membuat suatu perancangan kampanye kesadaran pola makan sehat khususnya untuk daerah Palembang tempat penulis tinggal dengan memperhatikan materi yang dibutuhkan oleh target sasaran. Melalui kampanye kesadaran masyarakat ini, diharapkan bisa membuat masyarakat meningkatkan kualitas hidup agar dapat memenuhi ketentuan hidup sehat dengan penuh kesadaran dan tingkat displin yang tinggi agar pola makan sehat yang dijalankan berdampak positif untuk kesehatan tubuh.

\section{A. Konsep Perancangan Media}

Perancangan kampanye kesadaran pola makan sehat bagi masyarakat Kota Palembang memiliki beberapa tahapan media yang digunakan pada perancangan. Melalui konsep media, diharapkan setiap media yang digunakan dapat memiliki fungsi dan cara pemakaian yang tepat, sehingga tujuan dari kampanye kesadaran ini dapat tercapai, adapun konsep-konsep media, yaitu meliputi tujuan media, strategi media, pemilihan media, khalayak sasaran, panduan media, program media, dan biaya kreatif.

Tujuan media kampanye kesadaran ini adalah untuk menyampaikan pesan kepada masyarakat secara luas dan kontinu, melalui pre media berupa flyer dan poster untuk awal pengenalan kepada masyarakat mengenai kampanye kesadaran pola makan sehat ini, kemudian di lanjut dengan main media berupa kartu kalori harian yang berisi tentang informasi berbagai kalori makanan sehingga masyarakat bisa mengontrol asupan kalori harian yang masuk ke dalam tubuh, kemudian di lanjut dengan follow up media berupa t-shirt, lunch box, water bottle, notes, dan pin sebagai merchandise karena telah turut serta dalam kampanye kesadaran pola makan sehat ini.

Strategi media yang ditetapkan meliputi segmentasi media, panduan media, program media, dan biaya media. Pada perancangan kampanye kesadaran pola makan sehat bagi masyarakat kota Palembang ini menargetkan sasaran kepada masyarakat kota Palembang sebagai target primer dan masyarakat Sumatera Selatan sebagai target sekunder. Mengenai hal ini, strategi media yang digunakan merupakan media-media yang sangat dekat dengan masyarakat, namun dengan konsep perancangan yang komunikatif dan persuasif sehingga dapat dimengerti. Adapun media yang digunakan menggunakan ilustrasi yang sederhana, namun memiliki makna dalam penyampaian pesan.

Khalayak sasaran merupakan target sasaran atau sasaran penerima dari suatu pesan. Pada perancangan kampanye kesadaran pola makan sehat bagi masyarakat kota Palembang ini menargetkan kepada masyarakat usia 20-30 tahun sebagai target primer, sedangkan orang dewasa usia 30-50 tahun sebagai target sekunder.

Perancangan media kampanye kesadaran pola makan sehat bagi masyarakat kota Palembang yang akan dirancang adalah dengan membuat gaya tampilan desain yang simple dan modern agar mudah menarik audiens untuk melihat. Dalam perancangan kampanye kesadaran masyarakat ini, penulis akan menampilkan visual berupa sumber pangan yang bernutrisi untuk tubuh. Selain itu, pemilihan warna-warna dan gaya tampilan desain pada media pendukung akan menggunakan warna-warna yang lembut dan ceria.

\section{B. Final Desain}

Dalam metode visualisasi desain terdapat tahap pra produksi yaitu dengan mempersiapkan mater-materi desain yang akan dilakukan penggarapan (produksi) untuk media elektronik maupun media cetak. Pada media cetak dilakukan perencanaan rancangan yaitu idea layout, rough layout, comperhensive layout, dan final desain.

1. Logo

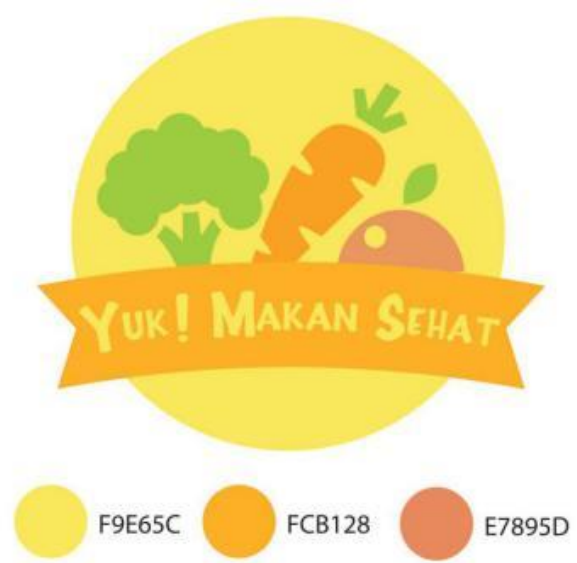

Gambar 5. Final Desain Logo Sumber: Dokumentasi pribadi Yuarisya N 


\section{Kamus Kalori Harian}

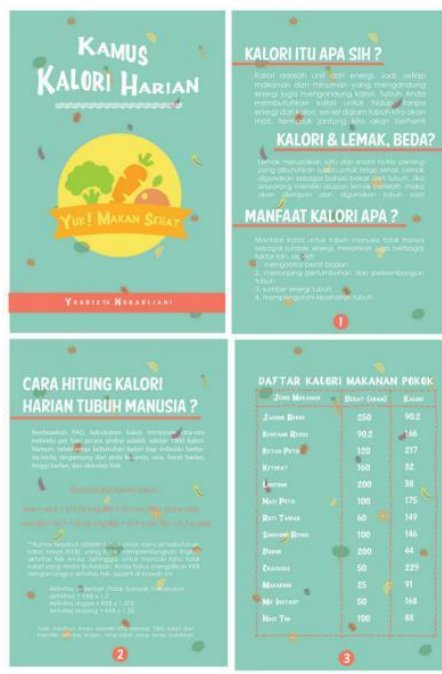

Gambar 6. Final Desain Kartu Kalori Harian Sumber: Dokumentasi pribadi Yuarisya N

3. Poster

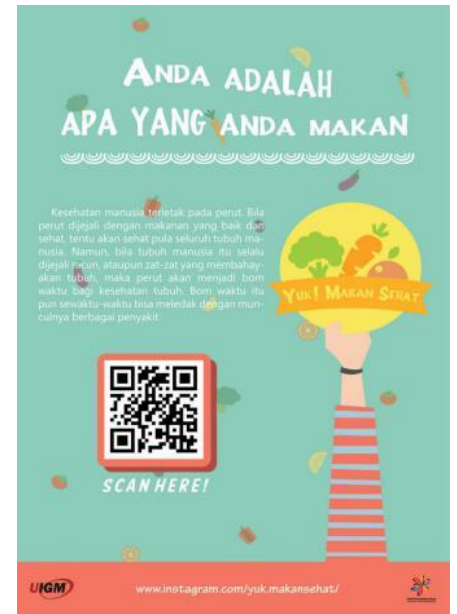

Gambar 7. Final Desain Poster Sumber: Dokumentasi pribadi Yuarisya N

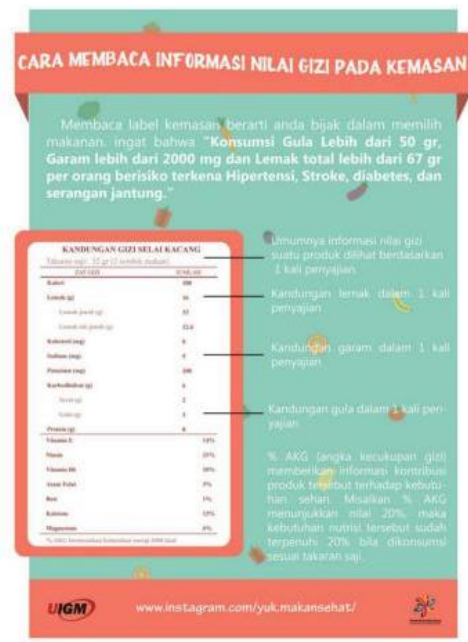

Gambar 8. Final Desain Poster 2 Sumber: Dokumentasi pribadi Yuarisya N

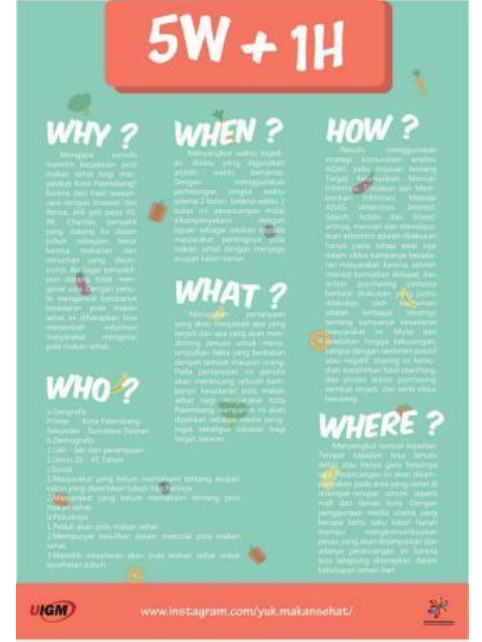

Gambar 9. Final Desain Poster 3 Sumber: Dokumentasi pribadi Yuarisya N

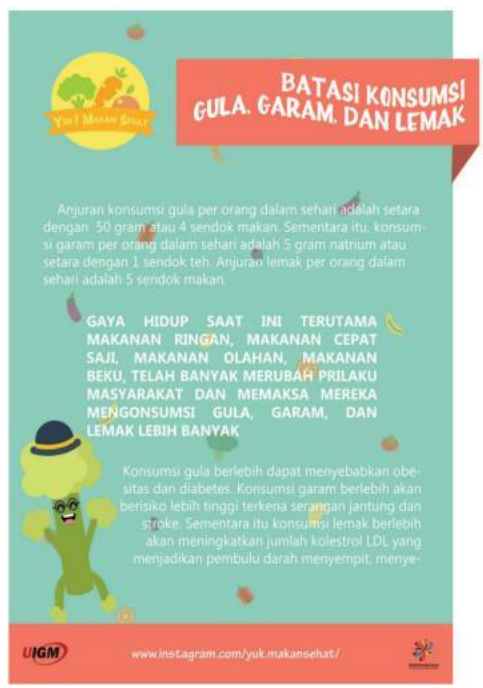

Gambar 10. Final Desain Poster 4

Sumber: Dokumentasi pribadi Yuarisya N

\section{Kesimpulan}

Dalam hal memilih makan memang terlihat sepele sehingga sering kali dilakukan tanpa pikir panjang dengan tujuan sederhana seperti hanya cukup dengan merasa kenyang dan memuaskan lidah serta keinginan. Padahal, pilihan makanan yang dipilih berefek sangat besar pada kesehatan dan kehidupan. Memilih makanan yang tidak sehat artinya tidak menghargai kesehatan. Memilih untuk memakan makanan yang tidak sehat artinya memberi tubuh risiko terkena gangguan kesehatan dan penyakit. Sebaliknya, memilih makanan yang sehat artinya menghargai dan menjaga kesehatan tubuh sendiri. Jadi, memilih makanan bukanlah hal yang sepele.

Pada Perancangan kampanye kesadaran pola makan sehat bagi masyarakat kota palembang ini memberikan berbagai informasi yang perlu diketahui oleh masyarakat mengenai pola makan sehat dengan metode menghitung asupan kalori harian untuk tubuh. Dengan seperti itu, 
maka masyarakat sudah mengurangi risiko terkena berbagai penyakit yang datang dari makanan.

\section{Daftar Pustaka}

A.M. Djelantik. 2004. Estetika Sebuah Pengantar. Bandung: Masyarakat Seni Pertunjukan Indonesia.

B, Sukarman. 2006. Estetika. Makassar: Jurusan Seni Rupa Universitas Negeri Makassar.

Bachrens, Inge Tumiwa. 2016. Langkah Mudah Membiasakan Makan Sehat. Jakarta: Kawan Pustaka.

David, Gillesple. 2015. Eat Real Food. Australia.

Dr. Jonathan Wright, MD and Linda Larsen, BS, BA. 2011. Eating Clean For Dummies. Canada.

Durianto, Sugiarto, Widjaja dan Supratikno. 2003. Inovasi Pasar Dengan Iklan Yang Efektif. Jakarta: PT. Gramedia Pustaka Utama.

Eric Schlosser. 2002. Fast Food Nation. England

Iswandi, Heri. 2018. Seni Mural Sebagai Unsur Politik Dalam Kehidupan Sosial. (Diakses pada 29 Oktober 2018)

Karl Weber. 2009. Food, Inc. United States of America.

Kusrianto, Adi. 2007, 2009. Pengantar Desain Komunikasi Visual. Yogyakarta: Penerbit Andi Offset.

Michael Moss. 2013. Salt Sugar Fat. Jakarta: PT. Gramedia Pustaka Utama.

Michael Polland. 2008. In Defense of Food. United States of America.

Peirce, Sanders Charles. 1991. Peirce On Signs: Writings On Semiotic. The University of North Carolina Press. London. 